\title{
THE INFLUENCE OF EMERGING ADULTHOOD STATUS AND SENSATION SEEKING ON FINANCIAL BEHAVIOR OF PETRA CHRISTIAN UNIVERSITY STUDENTS
}

\author{
Claudia ${ }^{1}$, Evelyn Setiawan ${ }^{2}$ \\ 1,2 Finance and Investment Program, \\ Faculty of Business and Economics, Petra Christian University \\ Jl. Siwalankerto 121-131, Surabaya

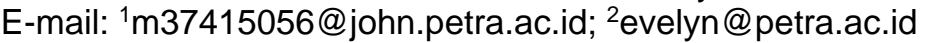

\begin{abstract}
This study aims to determine the effect of emerging adulthood status and sensation seeking on students' financial behavior. This type of research is descriptive with primary data sources. This study was conducted by distributing questionnaires to active undergraduate students at Petra Christian University. The 508 collected data were analyzed using SEM-AMOS 24. The results showed that emerging adulthood status had a significant effect on student's financial behavior while sensation seeking didn't have significant effect on students' financial behavior.
\end{abstract}

Keywords: Emerging adulthood status, financial behavior, sensation seeking.

\section{INTRODUCTION}

Individuals who have become students enter the age to stabilize their life establishment (Yusuf, 2012). The most prominent characteristics of students are independence and having goals for the future (Siswoyo, 2007; Kurniawan et al., 2020). Students between the ages of 18 and 25 are in the conditon of imbalance between the characteristics of students who should be independent and have goals but must also try to adapt to the lecture environment (Yusuf, 2012; Siswoyo, 2007). Students do not want to be called adolescents. However, they are also not ready to be called adults because they are still exploring their identities and are still filled with instability in determining the future (Reifman, Arnett, \& Colwell, 2007). This period of instability is a transitional period between adolescence and early adulthood called emerging adulthood status. Other characteristics of emerging adults are unstable financial situations, interpersonal relationships, living arrangements, emotional development, and trust (Arnett, 2000).

Students who are in the age range of 18 to 25 years are identical to the age of self-exploration (Reifman, Arnett, \& Colwell, 2007). This causes students to be known as personal sensation seekers. Sensation seeking is a personality that likes to seek new experiences and risks as a source of pleasurable arousal (Zuckerman, 1979). Sensation seeking can also occur because of social interaction with peers so that students are vulnerable to the demands of becoming sensation seekers.

Another problem arises because, for most students, the college period is the first time where students manage their finances without the full supervision of their parents (Sabri et al., 2008). Financial management is part of the financial behavior of student (Kurniawan et al., 2020). Financial behavior can be defined as a psychological approach such as the characteristics, properties, and experiences of money management to explain how a person's behavior affects decisions and uses resources related to the financial sector, which will greatly affect the welfare of an individual (Ackert \& Deaves, 2010).

Financial behavior is influenced by emerging adulthood status. Emerging adults who are just about to embark on a journey to financial freedom greatly affect financial behavior, especially regarding how to manage finances in the present and future (Sinha, Tan, \& Zhan, 2018). To become an 
emerging adult who has qualities to be called an adult, the individuals should be able to accept responsibility, make independent decisions, and be able to be financially independent by applying good financial behavior (Arnett, 1998; Greene, Wheatley, \& Aldava, 1992; Arnett, 2000; Wahono \& Pertiwi, 2020).

Financial behavior is also influenced by sensation-seeking (Worthy, Jonkman, \& Blinn-Pike, 2010). Students whose peers demand to have a consistent tendency to become personal sensation seekers cause students to spend more than their daily needs and take financial risks to seek sensation (Zuckerman, 2007). An individual's financial behavior is strongly influenced by the irrational use of money for sensation seeking and the courage to use money, savings, and even debt to meet the satisfaction of sensation seeking (Bearden \& Haws, 2012).

This study aims to analyze the effect of emerging adulthood and sensation seeking on financial behavior students. Students who should use their time and financial resources during lectures to solidify life goals and financial goals cannot be optimal because they are in an era of emerging adult which is full of instability and peer demands for sensation seeking. The research was carried out on students of Petra Christian University, which is the best private university in Indonesia, located in Surabaya with A accreditation for college and the excellent campus award indicates that Petra Christian University, with good facilities and quality in various aspects of the BAN-PT accreditation criteria, can produce quality students, including having good financial behavior.

\section{LITERATURE REVIEW}

\section{Financial Behavior}

Financial behavior is a psychological approach to explain how a person's behavior affects decisions related to finance, which will significantly affect the welfare of an individual (Ackert \& Deaves, 2010). According to Xiao, Tang, \& Shim (2009), student's financial behavior is related to expense management, balance control, and saving. Expense management can be measured by recording routine expenses, spending according to a predetermined budget, and checking every note received carefully. Balance control can be measured by the behavior of maintaining an adequate balance in savings account and paying bills or debts on time. Saving can be measured from saving regularly, setting aside emergency funds, and setting aside funds for investment.

\section{Emerging Adulthood Status}

Emerging adulthood is a transitional period between adolescence and early adulthood experienced by individuals aged 18-25 years. The transition from addiction in adolescence to adulthood results in emerging adults not having clear normative responsibilities so that they tend to explore various directions of decision making that have many opportunities, and the future is still uncertain (Arnett, 2000). Compared with individuals who have entered adulthood, emerging adults have the characteristics of less stable financial situations, interpersonal relationships, living arrangements, cognitive and emotional development, and trust (Arnett, 2000).

The essential characteristic of emerging adulthood is demographic transition, but its main focus is on developing individual character qualities (Arnett, 1998). The two main criteria are accepting responsibility and making independent decisions (Arnett, 1998; Greene, Wheatley, \& Aldava, 1992). The third criterion is financial independence (Arnett, 2000). These three criteria reflect the independence of the individual to prepare himself as an adult.

\section{Sensation Seeking}

Sensation seeking is a tendency to seek new extraordinary and complex experiences as a source of excitement that is fun even though it is risky (Zuckerman, 1979). Sensation seeking can be measured using a sensation seeking scale (SSS-V) (Zuckerman \& Kuhlman, 2000). According to Zuckerman (1979), four scales represent various models of sensation-seeking that contribute to 
the individual personality structure, namely thrill and adventure-seeking (TAS), experience seeking. (ES), disinhibition (Dis), boredom susceptibility (BS).

\section{The Relationship between Concepts}

\section{Influence of Emerging Adulthood Status on Financial Behavior}

Emerging adults who are just about to embark on a journey to financial freedom greatly influence financial behavior, especially regarding financial management in the present and future (Sinha, Tan, \& Zhan, 2018). To become an emerging adult who has character qualities, individuals should accept responsibility, make independent decisions, and be financially independent by applying good financial behavior (Arnett, 1998; Greene, Wheatley, \& Aldava, 1992; Arnett, 2000). Good financial behavior in emerging adults can be seen from the management of pocket money related to expense management, balance control, and saving (Xiao, Tang, \& Shim, 2009). Good financial behavior in emerging adults will continue to improve future economic welfare and influence financial habits throughout one's lifetime (Sinha, Tan, \& Zhan, 2018; Shim, Serido, Tang, \& Card, 2015; Olshavsky \& Granbois, 1979).

\section{The Effect of Sensation Seeking on Financial Behavior.}

Environmental factors play a role up to $40 \%$ in stimulating sensation-seeking. Observation, imitation, and social interaction with peers and the media allow a person to study behavior categorized as sensation seeking. Peer demands trigger individuals to have high sensation seeking with a consistent tendency to seek new stressful, interesting, and unknown activities. This results in individuals having to spend more than their daily needs and take financial risks for the sake of experiencing sensation seeking (Zuckerman, 2007). An individual's financial behavior becomes unhealthy because they don't think too rationally about using the money for this experience and dare to use savings and even go into debt to get satisfaction from sensation seeking (Zuckerman \& Kuhlman, 2000; Bearden \& Haws, 2012).

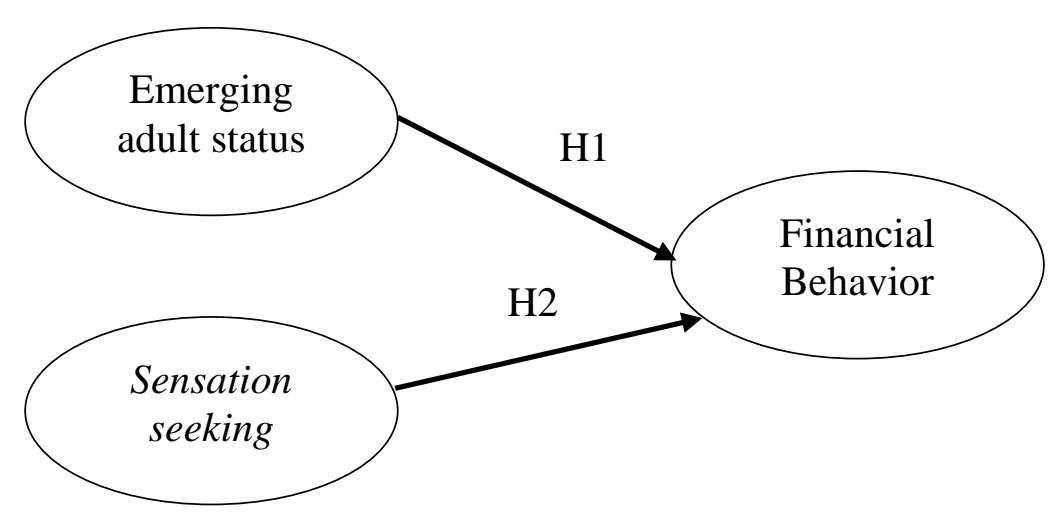

Figure 1. Conceptual Model Research

$\mathrm{H1}$ : Emerging adult status has a significant effect on the financial behavior of Petra Christian University students.

H2: Sensation seeking has a significant effect on the financial behavior of Petra Christian University students.

\section{METHODOLOGY}

The type of research carried out in this research is associative and quantitative. According to Supriyanto (2009), associative research is a research method to determine the effect of two or more variables. The quantitative method itself uses numerical data and can be calculated using statistical methods (Kuncoro, 2003). The variables of this study were emerging adulthood status, 
sensation seeking, and financial behavior. The dependent variable of this research is emerging adulthood status and sensation seeking, while the independent variable of this study is financial behavior. The population of this study was students at Petra Christian University. The sampling technique was purposive sampling. The sample of this study amounted to 368 respondents using the criteria for active undergraduate Petra Christian University students aged 18 to 25 years. This research uses primary data taken directly from individuals or related people. The primary data source comes from answers to questionnaires that have been distributed to respondents.

\section{Operational Definition of Variable}

1) Financial Behavior, namely the behavior of active undergraduate students at Petra Christian University in managing financial resources.

2) Emerging Adulthood Status, namely the level of maturity of active undergraduate students at Petra Christian University during the transitional period between adolescence and adulthood.

3) Sensation Seeking is the personality of Petra Christian University undergraduate students who like to seek sensations through new experiences.

\section{Data Analysis Techniques}

The data processing is carried out using SEM with AMOS 24 program. The steps that need to be taken are creating a theory-based SEM model, determining the degree of freedom, fulfilling the assumptions and requirements of SEM, test the validity and reliability, and evaluating the criteria goodness of fit.

\section{ANALYSIS AND DISCUSSION}

\section{SEM Model SEM}

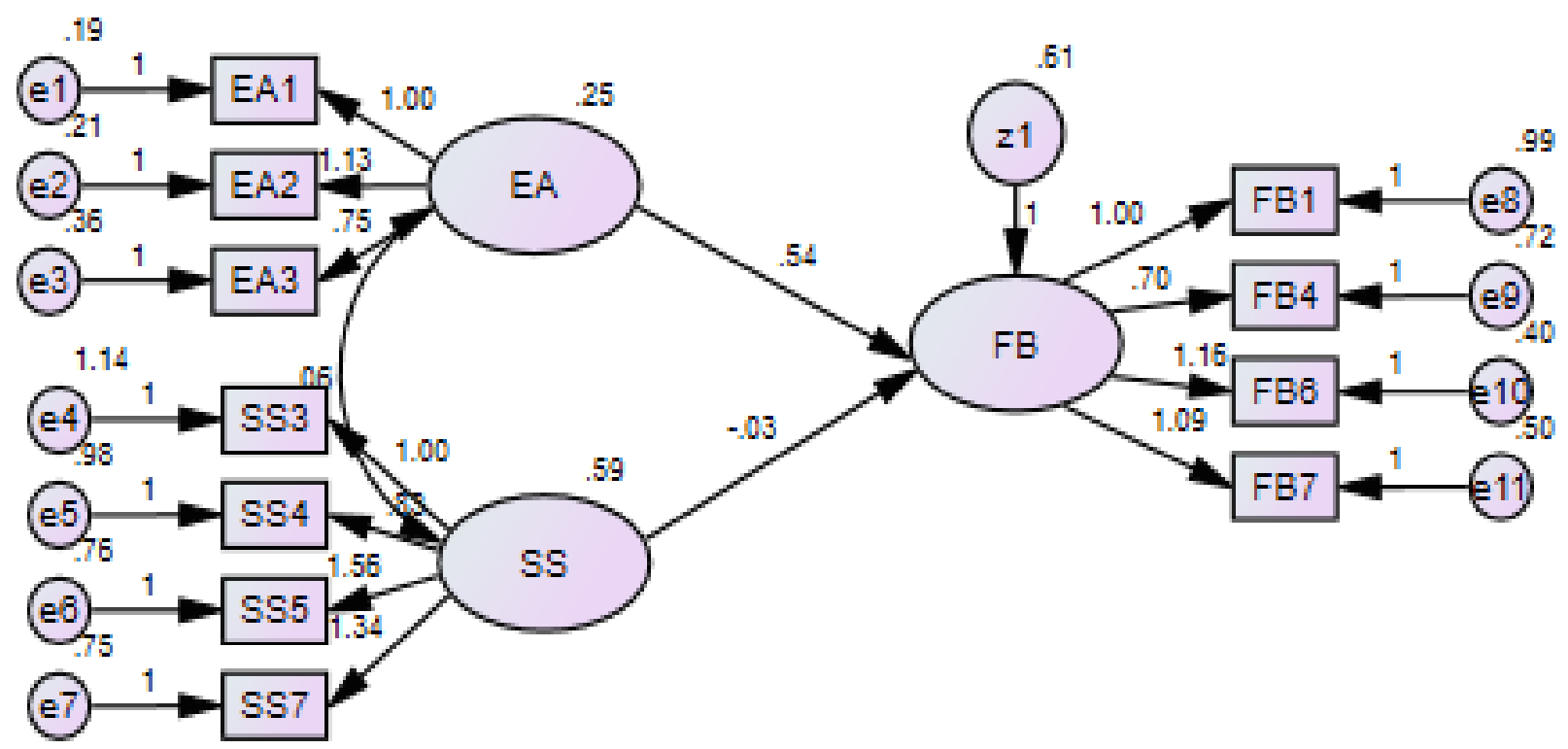

Figure 2. SEM Model Research

Tested model with index goodness of fit, and it was found that 7 (seven) indices were not fulfilled, so they needed to be modified: 


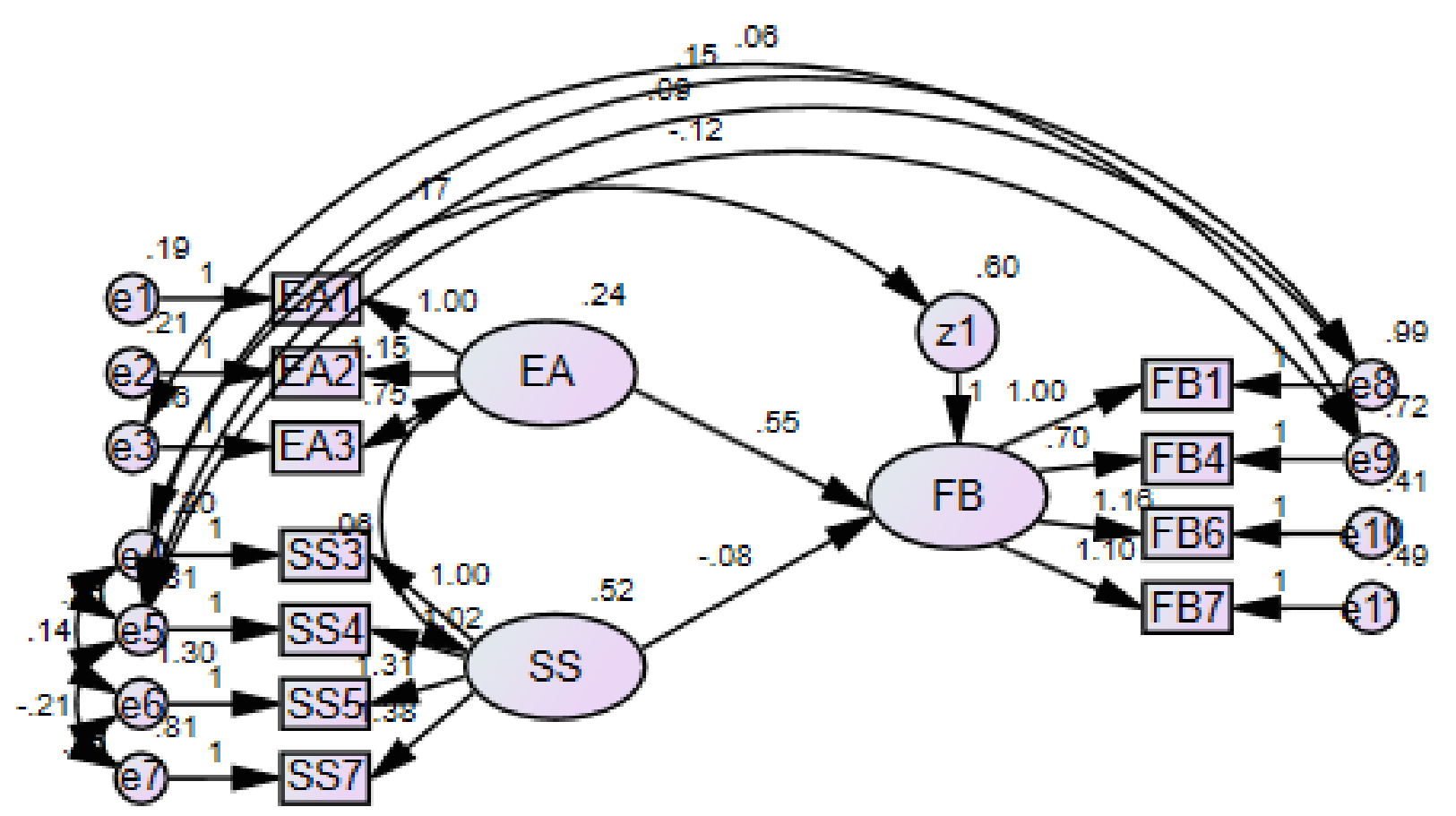

Figure 3. SEM Model Modified

After the SEM model was modified, every index goodness of fit was fulfilled.

\section{Hypothesis}

Hypothesis Testing is seen from the $p$-value. $\mathrm{H}_{0}$ is rejected if the $p$-value is $<0.05$.

\begin{tabular}{llcccc}
\hline & & Estimate & SE & CR & P \\
\hline FB $<--$ & EA & .545 & .102 & 5.320 & ${ }^{\star \star \star}$ \\
FB $<--$ & SS & -.085 & .072 & -1176 & .240 \\
\hline
\end{tabular}

Hypothesis test results state that emerging adulthood status significantly influences financial behavior, while sensation-seeking does not significantly affect financial behavior.

\section{Discussion}

Based on the results of hypothesis testing, it is known that there is a significant influence between emerging adulthood status and the financial behavior of active undergraduate students at Petra Christian University. The more mature a student, the financial behavior is better. Conversely, if students have a high dependence on other people, such as when they were still teenagers, it will result in bad financial behavior.

The characteristics of the respondents become reinforcing evidence that active undergraduate students of Petra Christian University are ready to be called adults. Students who come from outside Surabaya and live in a boarding house certainly have to manage their finances without full supervision from their parents. Outside Surabaya, students who live in Surabaya and live with their parents are also entrusted with managing their own pocket money because they are considered mature enough to manage personal finances. Student personal financial management can be seen from the provision of student allowances, the majority of which is given every month. The use of the allowance for any matter depends on the decision of each individual. Active undergraduate students of Petra Christian University can meet their own financial needs from the allowance that has been received and can be said to be responsible for managing their personal finances because they are still able to set aside money for regular savings and set aside money for emergency funds. 
Based on the results of hypothesis testing, it is known that there is no significant influence between sensation seeking and the financial behavior of active undergraduate students at Petra Christian University. Active undergraduate students of Petra Christian University are only dominant in experience seeking and boredom susceptibility. Sensation seeking that is often done by active undergraduate students of Petra Christian University is going out with friends, hang out, traveling without prior planning, trying new cafes or eating places. This is because observation, imitation, and social interaction with peers and the media allow a person to study behavior that is categorized as sensation seeking (Zuckerman, 1991). Some of these habits cause individuals to spend more than their daily needs and take financial risks to satisfy experiences sensation seeking (Zuckerman, 2007). Some students still like sensation seeking with a tendency to seek new and enjoyable experiences, even though they are risky, through going to clubs, consuming alcoholic drinks, but not in large quantities. Although not significant, it can be seen in the table above that the effect is negative. It can be said that sensation seeking has an inversely proportional impact on students' financial behavior even though it is not significant. The more a student seeks sensation, the more problematic the financial behavior is going to be.

The respondents' answers conclude that most active undergraduate students at Petra Christian University have enough pocket money to meet daily needs and even with an excess, it can seen from the socio-economic status of their parents and the results of additional questionnaire questions that state that students are not reluctant to use their money for excessive shopping and hangouts because students spend their money without thinking about their planned budget and reexamining every purchase note has been made, which is very rarely done by active undergraduate students of Petra Christian University. By having sufficient or even excess pocket money, even though student expenses are not 'controlled', there is still money left over to save and prepare as an emergency fund.

\section{CONCLUSIONS AND RECOMMENDATIONS}

Based on the analysis and discussion that has been carried out, the researchers found the following conclusions:

1. There is a significant influence between emerging adulthood status and the financial behavior of active undergraduate students at Petra Christian University.

2. There is no significant effect between sensation seeking and the financial behavior of active undergraduate students at Petra Christian University.

This study has several limitations, so the researchers hope that further researchers can develop this research by:

1. The drawbacks of this reserach are the lack of respondents' openness to reveal facts about sensation seeking carried out because data collection was carried out using a questionnaire. The next researcher can conduct in-depth interviews to capture the phenomenon more deeply, and the students being interviewed can be more open.

2. Parents should understand sensation-seeking by students for emerging adult, examples such as hanging out excessively, trying new food, and preferring to travel than at home, so that parents can direct students to reduce sensation-seeking that affects their financial behavior.

3. Students can maintain the level of maturity in the period emerging adult, reduce sensationseeking, and develop financial behavior in personal financial management by starting with making and adhering to a priority scale of expenditure, recording every expense, and setting money aside for savings and emergency funds.

4. Student organizations, especially those from the Financial Management program, create programs that can develop financial behavior regarding personal financial management for Petra Christian University students. 


\section{REFERENCES}

Ackert, L., \& Deaves, R. (2010). Behavioral Finance: Psychology, Decision-Making and Markets. Mason, USA: South-Western Cengage Learning.

Arnett, JJ (2000). Emerging Adulthood: A Theory of Development from the Late Teens Through the Twenties. American Psychologist, 55, 469-480.

Arnett, JJ (1998). Learning to Stand Alone: The Contemporary American Transition to Adulthood in Cultural and Historical Context. Human Development, 41, 295-315.

Bearden, \& Haws, N. (2012). Handbook of Marketing Scales: Multi-ltem Measures or Marketing and Customer Behavior Research (3th ed.). California: SAGE.

Greene, AL, Wheatley, SM, \& Aldava, JF (1992). Stages on Life's Way: Adolescents' Implicit Theories of the Life Course. Journal of Adolescent Research, 7, 364-381.

Kuncoro, M. (2003). Research Methods for Business \& Economics. Jakarta: Erlangga.

Kurniawan. J. Y., Malelak, M. I., \& Astuti, D. (2020). Pengaruh attitude, subjective norm, past behavior, dan perceived control terhadap budgeting intention mahasiswa di Surabaya. International Journal of Financial and Investment Studies (IJFIS), 1(1), 21-29. https://doi.org/10.9744/ijfis.1.1.21-29

Olshavsky, RW, \& Granbois, DH (1979). Consumer Decision Making: Fact or Fiction? The Journal of Consumer Research, 6 (2), 93-100.

Reifman, A., Arnett, JJ, \& Colwell, MJ (2007). Emerging Adulthood: Theory, Assessment, and Application. Journal of Youth Development, 2 (1).

Ristekdikti. (2017). List of 100 Non-Polytechnic Higher Education Rankings in Indonesia in 2017. Retrieved from Ristekdikti: http://kelembentuk.ristekdikti.go.id/index.php/2017/08/18/daftar-100-perlai-perguruantinggi-non-politeknik-tahun-2017

Sabri, ea (2008). Financial Behavior and Problems among College Students in Malaysia: Research and Education Implication. Consumer Interests Annual, 54, 166-170.

Shim, S., Serido, J., Tang, C., \& Card, N. (2015). Socialization Processes and Pathways to Healthy Financial Development for Emerging Young Adults. Journal of Applied Developmental Psychology, 38, 29-38.

Sinha, G., Tan, K., \& Zhan, M. (2018). Patterns of Financial Attributes and Behaviors of Emerging Adults in the United States. Children and Youth Service Review, 93, 178-185.

Siswoyo, D. (2007). Science Education. Yogyakarta: UNY Press.

Supriyanto. (2009). Business Research Methods. Jakarta: PT Index.

Worthy, SL, Jonkman, J., \& Blinn-Pike, L. (2010). Sensation-Seeking, Risk-Taking, and Problematic Financial Behaviors of College Students. Journal of Family and Economic Issues, 31 (2), 161-170.

Wahono, H. K., \& Pertiwi, D. (2020). pengaruh financial literacy, materialism, compulsive buying terhadap propensity to indebtedness. International Journal of Financial and Investment Studies (IJFIS), 1(1), 114. https://doi.org/10.9744/ijfis.1.1.1-14

Xiao, J., Tang, C., \& Shim, S. (2009). Acting for Happiness: Financial Behavior and Life Satisfaction of College Students. Social Indicators Research (92), 53-58.

Yusuf, S. (2012). Developmental Psychology of Children and Adolescents. Bandung: Youth Rosdakarya.

Zuckerman, M. (2007). Sensation Seeking and Risky Behavior. Washington DC, US: American Psychological Association.

Zuckerman, M. (1979). Sensation-Seeking: Beyond the Optimal Level of Arousal. Hillsdale: Lawrence Erlbaum.

Zuckerman, M., \& Kuhlman, DM (2000). Personality and risk-taking: Common biosocial factors. Journal of Personality, 68, 999-1029. 